\title{
Examining the values in life science curriculum in terms of "consistency"
}

\begin{tabular}{|c|c|}
\hline & $\begin{array}{c}\text { Cihat Yaşaroğlu } \\
\text { Bingöl University, Bingöl, Turkey }\end{array}$ \\
\hline Article history & \multirow{7}{*}{$\begin{array}{l}\text { We gain the values that guide human being's lifelong behaviors } \\
\text { during our social life from our family, peer groups, educational } \\
\text { institutions, media, and so on. Those values also form our evaluation } \\
\text { criteria. Considering that skills learned during childhood become } \\
\text { permanent, values that are taught to students must be in integrity, } \\
\text { consistency and be in a form that does not make any conflict for } \\
\text { student. Handling the issue in this context, the values included in Life } \\
\text { Science Course Curriculum (LSCC) have to be examined in terms of } \\
\text { consistency. This study aims to find out consistency in values } \\
\text { included in LSCC distributed according to the classes and themes, } \\
\text { whether there are conflicting values, and also comparing values } \\
\text { according to the individuality and sociality. In this study, document } \\
\text { analyses method has been used. Primarily, the values included in } \\
\text { LSCC have been determined. Distributions of values according to the } \\
\text { classes and themes, presence of attribute of individuality or sociality, } \\
\text { and consistency of values have been examined. Based on analyzing } \\
\text { the collected data, the researcher has come to the conclusion that } \\
\text { "patriotism" is the most emphasized value and it is available in each } \\
\text { class and theme. Additionally, love, tolerance, respect and justice are } \\
\text { the most repeated values. Truthfulness, honesty and peace are the least } \\
\text { repeated values in all classes. }\end{array}$} \\
\hline $\begin{array}{l}\text { Received: } \\
\text { 27.12.2014 }\end{array}$ & \\
\hline $\begin{array}{l}\text { Received in revised form: } \\
24.02 .2015\end{array}$ & \\
\hline Accepted: & \\
\hline & \\
\hline & \\
\hline $\begin{array}{l}\text { Life Science, Values, } \\
\text { Consistency }\end{array}$ & \\
\hline
\end{tabular}

\section{Introduction}

The definition of the values, the importance of the values in personality development, and the approaches to the education of values should be briefly mentioned primarily in order to evaluate the values in Life Studies in terms of consistency.

When the definition of value is reviewed, it is seen that the social scientists define it in a different manner. However, in the light of the characteristics and definitions given by the researchers and scientists such as Allport, Feather, Inglehart, Kohn, Kluckhon, Morris, and Rokeach, it can be defined value as "the criteria or belief(s) going beyond a certain situation or action; sorted in order of priority by associating with each other; ensuring a motivation towards the objects desired; and providing guidance in preferences or evaluations" (Shwartz, 2012).

Also, personality that is in a close relation with value refers to the total of characteristics

\footnotetext{
*Corroespondency: cyasaroglu@bingol.edu.tr
} 
which distinguish individuals from each other and possessed from the birth or gained afterwards. Our values and characteristic properties are also one of the elements forming our personality (Senemoğlu, 2004). The personality characteristics must be consistent with each other (Cüceloğlu, 1999). Comparing the personality and value, Bilsky and Schwartz (1994) suggest that there is a difference on these three points: (1) While the characteristics of personality are generally seen as the explanations of the observed behavior patterns, the value is considered as the judgments of the individuals on whether the situations, people or behaviors are desired or not. (2) While the differentiation in the characteristics of personality is also an indication of the characters displayed by the individuals, the values show difference in terms of the importance attributed to certain targets by the individuals. (3) While the characteristics of personality explain what kind of characteristics of personality the behavior is originated regardless of the intention, the values refer to the intentional targets of the individuals which show their consciousness.

In order to evaluate the values available in the program in terms of the collectivism and individualism, the approaches for the education of values should be observed. The education of values is moreover referred with different titles including moral education, character education, and education of ethics (Lovat, Toomey, \& Clement, 2010). The traditional character education accepts students as passive receiver of the social values. On the other hand, in the modern approach of the character education, it is argued that critical thinking should be included in the process of education of values rather than only shaping the students in accordance with certain values. Values clarification is based upon the principle of values relativity. The focus point of the values clarification is the development of the individual's autonomy. The excessive responsibility loaded on the individual for establishing their own values is one of the leading reasons making this approach individualistic (Altıntaş, 2012). While certain value approaches centralize the individualism, some of them centralize the collectivism. Accordingly, it can be analyzed that which viewpoint is adopted in the Life Science Course Curriculum (LSCC).

According to Tozlu (2003), the values not only are developed in an individual but also developed the individual itself by rendering human as a part of a community or a whole. The societies where the values are experienced can be defined as healthy societies. Then, it can be stated that this expression highlighted further emphasis on the social aspect of the values.

On the other hand, it can be seen two major opinions about educational policy in Turkish Educational System. Prens Sabahattin, Sat1 Bey, and Abdullah Cevdet described education as an individual process. According to this aspect persons must be considered and put forward in education. On the contrast Ziya Gökalp, İ. Hakkı Baltacioğlu, and Ethem Nejat accepted education as an agent for transition of cultural heritage (Tezcan, 1997). Prens Sebahattin can be seen as individualist and Ziya Gökalp as socialist in terms of values.

In the literature review, there are certain studies on how the values are included in various curriculums. For instance, Candan and Ergen (2014) studied on how humanist values considered in Life Science course books. In another research, Yaşaroğlu (2014) examined on the importance of values in Life Science Curriculum. Y1lmaz (2013) investigated pre-school teachers' opinions about Social Science curriculum in context of values. Çekin (2012) examined acquisitions of the course of Religion Culture and Knowledge of Ethics in according to the values. Merey, Kuş and Karatekin (2012) compared Social Science curriculum in Turkey and USA. 


\section{Method}

In this recent study, document analysis method has been used. This method includes "the analysis of written materials including information about the case or cases required to be researched" (Yıldırım and Şimşek, 2011, p.187). In this study, the objectives and personal qualities in "Life Science Course Curriculum Program and Instructions for the $1^{\text {st }}, 2^{\text {nd }}$, and $3^{\text {rd }}$ Classes in Primary School" (Ministry of National Education, 2009) have been analyzed. The values associated with the objectives have been analyzed in terms of the distributions as per classes and themes and the consistency in the personality characteristics to be gained. When analyzing the consistency of the characteristics to be provided for the individuals, the values are primarily divided in two groups as personal and social values. In this separation, the benefit to be provided by the values has been taken into consideration. If the personal benefits dominate, it is referred as "personal value", and if the social benefits dominate, the values are defined as "social values". From this point, the value of "openness to innovation" is classified as personal value and "tolerance, love, respect, peace, helpfulness, truthfulness, honesty, justice, patriotism, and cultural values protection" are categorized as social values.

\section{Results}

The Life Science course has been taught on the first three years of the primary school. It is composed of three themes as "My School Excitement", "My Unique Home", and "Yesterday, Today, Tomorrow". The distribution of the values according to the classes and themes are shown in Table-1.

Table 1. Distribution of Values to Themes and Classes

\begin{tabular}{|c|c|c|c|c|c|c|c|c|c|c|}
\hline \multirow{2}{*}{ Value } & \multicolumn{3}{|c|}{$\begin{array}{l}\text { My School } \\
\text { Excitement }\end{array}$} & \multicolumn{3}{|c|}{ My Unique Home } & \multicolumn{3}{|c|}{$\begin{array}{l}\text { Yesterday, Today, } \\
\text { Tomorrow }\end{array}$} & \multirow{2}{*}{ Total } \\
\hline & $\begin{array}{l}1^{\text {th }} \\
\text { class }\end{array}$ & $\begin{array}{l}2^{\text {nd }} \\
\text { class }\end{array}$ & $\begin{array}{l}3^{\text {th }} \\
\text { class }\end{array}$ & $\begin{array}{l}1^{\text {th }} \\
\text { class }\end{array}$ & $\begin{array}{l}2^{\text {nd }} \\
\text { class }\end{array}$ & $\begin{array}{c}3^{\text {th }} \\
\text { class }\end{array}$ & $\begin{array}{l}1^{\text {th }} \\
\text { class }\end{array}$ & $\begin{array}{l}2^{\text {nd }} \\
\text { class }\end{array}$ & $\begin{array}{l}3^{\text {th }} \\
\text { class }\end{array}$ & \\
\hline tolerance & 7 & 2 & 4 & 3 & & 4 & & & & 20 \\
\hline love & 3 & 3 & 4 & 4 & 2 & 5 & & & & 21 \\
\hline respect & 6 & 1 & 3 & 2 & 2 & 4 & & & & 18 \\
\hline peace & 1 & 2 & 3 & 1 & & 1 & & & & 8 \\
\hline helpfulness & 2 & 3 & 2 & 1 & 1 & & & 1 & & 10 \\
\hline truthfulness & 1 & 2 & 2 & & 1 & 1 & & & & 7 \\
\hline honesty & 1 & 2 & 2 & 1 & 1 & 1 & & & & 8 \\
\hline justice & 4 & 2 & 3 & 2 & 2 & 1 & & & & 14 \\
\hline openness to change & 1 & 2 & & 1 & 3 & 3 & 1 & 3 & 1 & 15 \\
\hline patriotism & 4 & 4 & 2 & 1 & 2 & 2 & 1 & 1 & 6 & 23 \\
\hline $\begin{array}{l}\text { cultural values } \\
\text { protection }\end{array}$ & 2 & 3 & & & 1 & 2 & 1 & 1 & 4 & 12 \\
\hline Total & 32 & 26 & 25 & 16 & 15 & 24 & 3 & 6 & 11 & 156 \\
\hline
\end{tabular}

In Table 1, it is seen that the most emphasized value is patriotism (23 attainments) when the frequencies of the values in three classes are sorted. Love (21 attainments), tolerance (20 attainments), and respect (18 attainments) values follow it respectively. It is also seen that the least emphasized last three values are truthfulness ( 7 attainments), peace ( 8 attainments), and honesty ( 8 attainments) values respectively.

When the available values in the program analyzed, it is observed that all values are consistent with each other and can give positive personality characteristics.

It is additionally understood that the social values have much more density when the distributions of the values qualified as social and personal values. 
When the distributions of the values according to the classes are analyzed, it is observed that the most values are seen in $3^{\text {rd }}$ class objectives ( 60 objectives) and the least values are seen in $2^{\text {nd }}$ class objectives (48 objectives). In the $1^{\text {st }}$ class, 51 objectives are observed as related with the values. It can be said that the objectives according to the classes in a consistent and balanced distribution.

While there are 83 objectives associated with the values available in "My School Excitement" theme, the number of attainments in "My Unique Home" theme, and in "Yesterday, Today, Tomorrow" theme is 55 and 22 respectively. Thus, the order is as follows: "My School Excitement", "My Unique Home", and "Yesterday, Today, Tomorrow".

\section{Conclusion and Discussion}

Meanwhile, "patriotism" with 23 objectives is the most emphasized. It is available in each class and theme. "Truthfulness" is the least emphasized value. Being available in all themes of all classes, the value of "patriotism" principally shows the priority of the values desired to be given to the students via the curriculum prepared by the center (Ministiry of National Education). With regard to this finding, it can be stated that one of the most fundamental personality characteristics desired to be given to the students by The National Education System is patriotism. In the study done by Yaşaroğlu (2014) on the importance of values available in LSCC in accordance with the opinions of the class teachers, it is revealed that the value which is seen as the least important in comparison with the other values by the teachers is patriotism. Consequently, it cannot be suggested that the values which are paid importance and repeated frequently by the program are seen on the same level of importance by the teachers. It can be said that the regional differences can be available in the possible reasons of that result. The perception of the students can be studied as a separate research subject. Y1lmaz (2013) has a result in his study suggesting that the value of "patriotism" is seen as the most important value within the ranks for the importance of the values in the Social Studies course.

Love, tolerance, respect, and justice are the most repeated values in LSCC. Çekin (2012) reaches a result stating that the value of love is also one of the most emphasized values in lesson of Religious Culture and Ethics. According to Merey, Kuş and Karatekin (2012), these values are seen as the least emphasized in Social Studies Lesson in the primary schools in USA. It is observed that while the value of love is one of the most frequently emphasized value in the curriculum programs in Turkey, it has a much less emphasis in Social Studies in the primary schools in USA. Candan and Ergen (2014) suggest that "love" is the most mentioned value in Life Science textbooks.

Truthfulness, honesty, and peace are the least repeated throughout all three years in the program. In the Social Studies Lesson in primary schools in USA, the value of honesty is one of the least emphasized values. On that point, it can be said that the value of honesty is emphasized in the same way in similar lessons of both countries (Merey, Kuş and Karatekin, 2012). In the research conducted by Candan and Ergen (2014) for analyzing whether the textbooks of Life Studies include basic universal values, it is seen that the value of peace is one of the least mentioned values in comparison with the other related values.

The social values are much more in the program. The personal values constitute $10 \%$ of the total objectives. It can be interpreted as that the education system aims social people; 
traditional character education method is adopted; Ziya Gökalp's view is dominant in The Ministry of National Educational System. The value of openness to innovation, which is categorized as personal value, takes place in all themes except for "My School Excitement" theme in the $3^{\text {rd }}$ class and is emphasized mostly in the $2^{\text {nd }}$ class objectives. It can be thought that the openness to innovation which is a personal value and the social values such as love, respect, tolerance and etc. are on the same direction and aim to give positive personality characteristics. Thus, it can be said that the values do not contradict with each other and they have a consistency.

The distribution of the objectives according to the themes; however, is not balanced. 83 objectives in "My School Excitement" theme, 55 objectives in "My Unique Home" theme, and 22 objectives in "Yesterday, Today and Tomorrow" theme are associated with the values. The most emphasized value is in the "My School Excitement" theme and minimum rate is seen in "Yesterday, Today and Tomorrow" theme. When this finding is regarded, it can be said that the values are emphasized much more in the early terms of the school year and much less in the later terms. Accordingly, it can also be stated that this distribution is not consistent in accordance with the terms.

\section{Acknowledgment}

This paper presented at $9^{\text {th }}$ International Balkan Education and Science Congress, October 16-18, 2014, Edirne, Turkey

\section{References}

Altıntaş, M. E. (2012). Values education approaches from the perspective of the predicament between the individual and the community. Journal of Values Education, 10 (24), 3154.

Bilsky, W., \& Schwartz, S. H. (1994). Values and personality. European Journal of Personality, 8, 163-181.

Candan, D. G. \& Ergen, G. (2014). Analysis of the 3th class life science textbooks about that including basic universal values. Uşak University Social Sciences Journal. 7 (1), 134161.

Cüceloğlu, D. (1999). Human and its behavior. Istanbul: Remzi Publications.

Çekin, A. (2012). The acquisitions of course of religion culture and knowledge of ethics for elementary education in connection with values education: A content analyses. Journal of Academic Researches in Religious Sciences. 12 (2), 105-119.

Lovat, T., Toomey, R., \& Clement, N. (2010). International research handbook on values and student wellbeing. Springer.

Merey, Z., Kuş, Z. \& Karatekin, K (2012). Comparison of elementary social studies curricula of turkey and the united states on values education. Educational Sciences: Theory \& Practice. 12 (2). 1613-1632

Ministry of National Education. (2009). Life science course curriculum and instruction manual for $1^{\text {th }}, 2^{\text {nd }}$ and $3^{\text {th }}$ classes. Ankara: MNE Publications.

Senemoğlu, N. (2004). Development, learning and teaching. Ankara: Gazi Publications.

Schwartz, S. H. (2012). An overview of the schwartz theory of basic values. Online Readings in Psychology and Culture, 2(1). http://dx.doi.org/10.9707/2307-0919.1116

Tezcan, M. (1997). Sociology of education. Ankara

Tozlu, N. (2003). Thoughts on our educational problems. Ankara: Mikro Publications. 
Y1ldırım, A. ve Şimşek, H. (2011). Qualitative research methods in the social sciences. Ankara: Seçkin Publications.

Y1lmaz, S. (2013). Teacher candidates' views regarding the values aimed to be taught in social studies lessons. Adiyaman University Social Sciences Journal, 6 (14), 645-680.

Yaşaroğlu, C., (2014, September). The investigation of classroom teachers' views about life science curriculum in the context of values education", Paper presented at the V. European Conference on Social and Behavioral Sciences, Russia. 